\title{
Examination of Business Transformation Strategy: Building Bridges between IT and the Business
}

\author{
Prety Diawati, Phong Thanh Nguyen, Muhamad Rusliyadi, E. Laxmi Lydia, K. Shankar
}

\begin{abstract}
It can see that volatility of business cannot precedence. The transformation is not an option; it is imperative of business with cause of new technologies and, blurred industry boundaries, energy dynamics, globalization, regulation, digitalization or other factors. For staying ahead thinking companies launch transformations even when they retooling themselves or dominate a market. The objective of business transformations are always can deliver emulated results, sustainable and focused.
\end{abstract}

Keywords: Business transformation, control, digitalization, focused

\section{INTRODUCTION}

In reality of economic the complete business industry is disrupted, so new concern for business organization is the actionable intelligence. In the information age core assets of business are information and data, they are the source of critical enablers and revenue.

So as to receive the rewards of new advancements, the following stage in that data age and the computerized change developments, higher business deftness and the expanding job of all types of information and data.

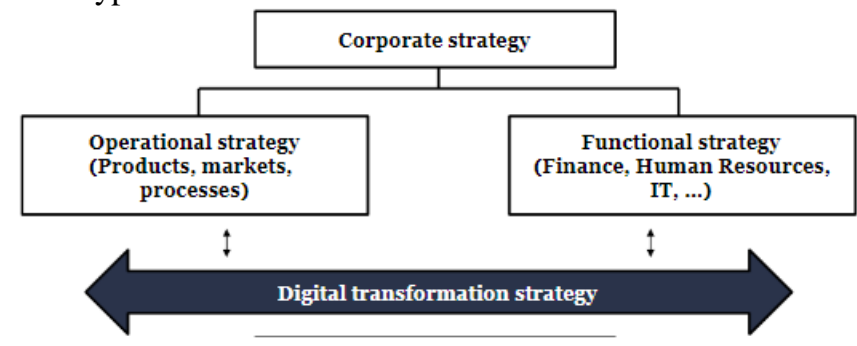

Figure 1: Corporate strategy and digital transformation strategy connection

Revised Version Manuscript Received on 16 September, 2019.

* Correspondence Author

Prety Diawati, Politeknik Pos Indonesia, Indonesia. E-mail: pretydiawati@poltekpos.ac.id

Phong Thanh Nguyen*, Department of Project Management, Ho Chi Minh City Open University, Vietnam. E-mail: phong.nt@ou.edu.vn

Muhamad Rusliyadi, Polytechnic of Agricultural Development Yogyakarta-Magelang, Agricultural Extension and Human Resource Development Agency, Ministry of Agriculture, Indonesia.

E. Laxmi Lydia, Professor, Vignan's Institute of Information Technology(A), Department of Computer Science and Engineering, Visakhapatnam, Andhra Pradesh, India. E-mail: elaxmi2002@yahoo.com

K. Shankar, Department of Computer Applications, Alagappa University, India. E-mail: shankarcrypto@gmail.com economy, associations should be prepared for quickening

In a business reality where 'the business', with a main (yet, non-select) job for promoting and the CMO, progressively takes choices on innovation spending plans, we see that it's regularly hard for IT and data the board experts, who are fundamental in advanced change, to communicate in the language of the CMO or different business officials, which customarily didn't have a place with their 'intended interest group'.

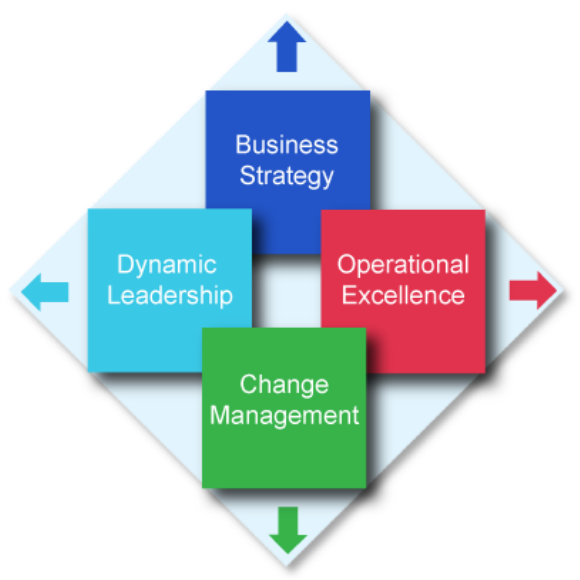

Figure 2: Business Transformation strategy

\section{Transformation BUILDING BLOCKS}

Effective transformations might be generally uncommon, yet they do exist - and yours can prevail too. A change, in this unique situation, is a noteworthy move in an association's capacities and personality with the goal that it can convey significant outcomes, important to its motivation that it couldn't ace previously.

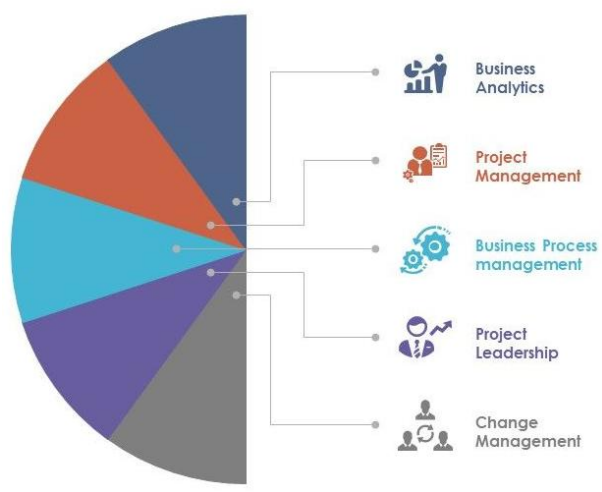

Figure 3: Business Transform Areas 
It always required highly engaged leaders and cultural shift at every place of organization. They can control the future of organization in the ways given below:

1. Treat your legacy as an asset. Spare the best of your past, strip the rest for favorable position, and utilize the salary to support what's to come.

2. Design for trust. Create approaches to draw in and merit the responsibility of everybody identified with your endeavor especially clients and workers.

3. Master the pivot from sprint to scale. Test new rehearses in an escalated, test, startup-style way. Pick the methodologies that work, and quickly execute them all through the bigger framework.

4. Create a strategic identity. Articulate a solitary attractive future for your endeavor and spotlight every one of your endeavors on accomplishing it.

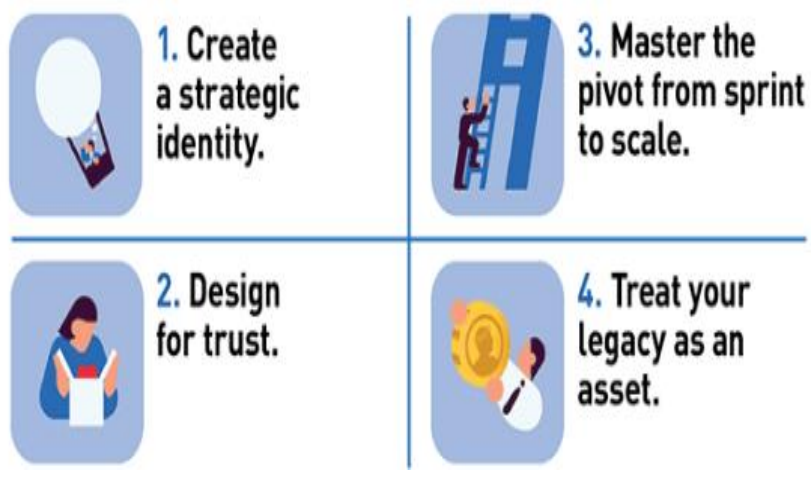

Figure 4: Building blocks of Transformation

For enterprise capabilities designing and defining six dimensions of comprehensive approach are given as follows:

1. Talent: The abilities, aptitudes, ability framework, and workforce arranging that empower an ideal ability base to execute the capacity.

2. Insights: The choice stream, data, and examination that drive educated and auspicious basic leadership.

3. Mission: The motivation behind ability, how it will work, and what worth it will convey. The mission is gotten legitimately from - and bolsters - the organization's procedure.

4. Processes: A coordinated and effective arrangement of procedures intended to accomplish the ideal results.

5. Integration: Clear jobs, choice rights, and arrangements that encourage mix inside and crosswise over different capacities, capacities, and associations.

6. Technology: For enabling the capability the required tools, hardware and software.

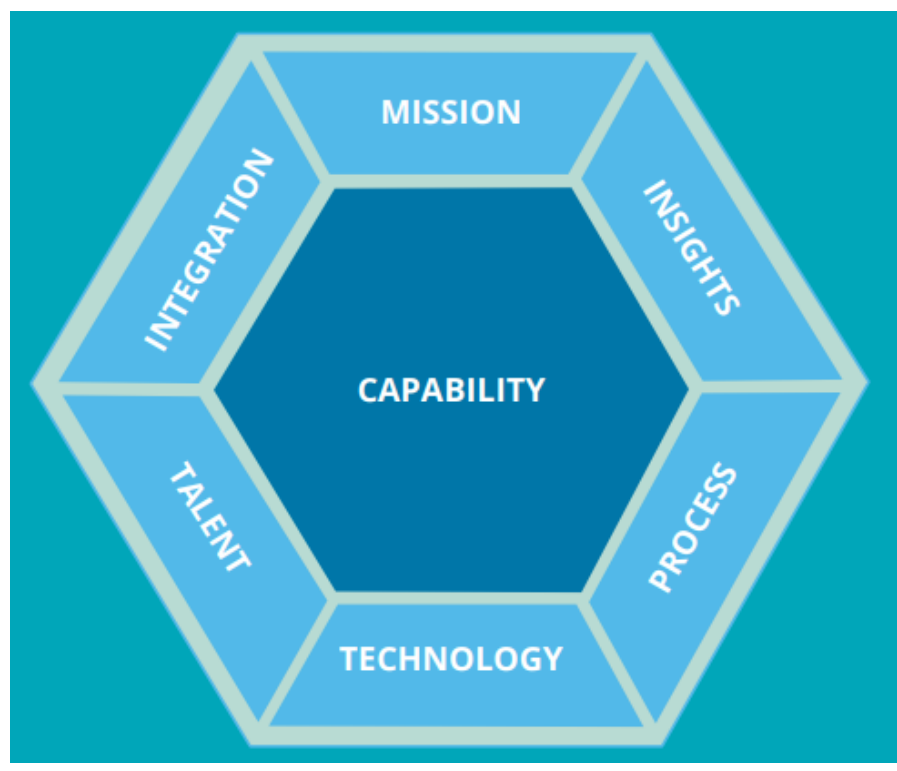

Figure 5: Enterprise capacity designing

\section{Digital Transform Strategy}

The digital transformation strategy can influence the strategy of customer and business experience and it can also influenced by them. Compliance, business, legal and technical functions of business are related with digital transformation. For finding a common language that can address their particular perspectives for helping these different domain experts, it can be behave as facilitator or translator.

A complete plan of strategic transformation can be build after agreed the digital strategy. The planning of digital transformation included following phases:

1. Identification of Technology

2. Gathering of Data

3. Resources Allocation

4. Determine Business Process

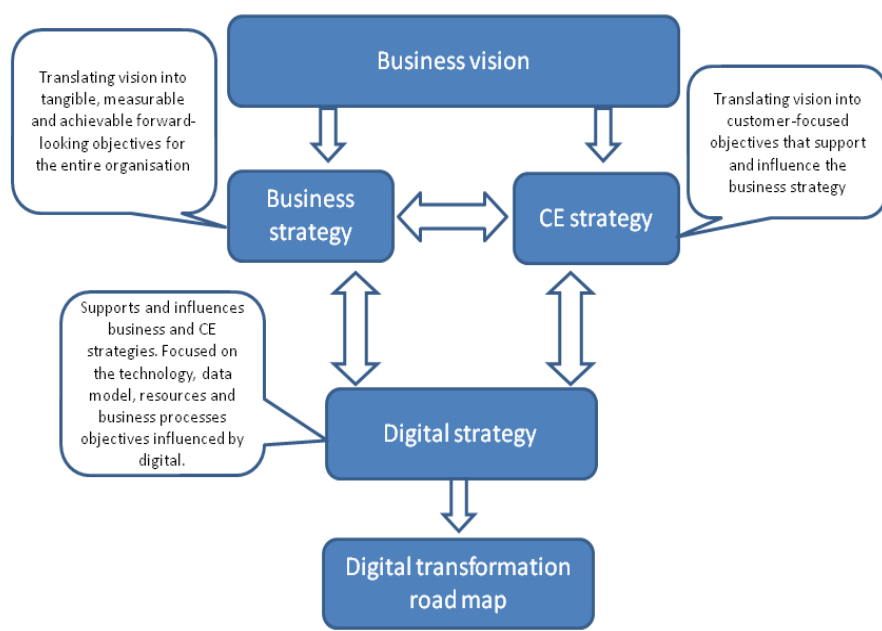

Figure 6: Digital Transform Strategy

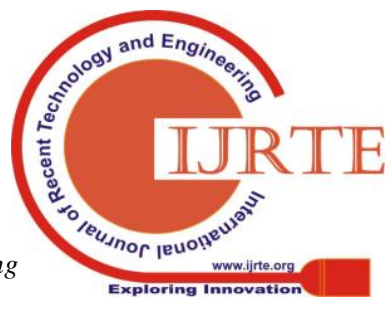




\section{INTEGRATION OF BUSINESS TRANSFORMATION STRATEGIES INTO BUSINESS}

The collaboration of business transformation strategies with business advancement and plans of action likewise should be surveyed from a duty point of view. Since business transformation methodologies cut crosswise over different procedures simultaneously, complex coordination endeavors may be required. Research ought to give rules to firms to help structure these procedures so as to accomplish shared objective setting, the arrangement of various techniques, and collaboration between different individuals and substances all through a business.

\section{CONCLUSION}

"Transformation" gets tossed around a great deal nowadays, yet it can have various implications for various people and organizations. In a universe of phenomenal disturbance and market choppiness, change today spins around the need to create new esteem - to open new chances, to drive new development, to convey new efficiencies. The objective is a transformation that is engaged, practical, and ready to convey quantifiable outcomes.

\section{REFERENCES}

1. Andal-Ancion, Cartwright, P.A. \& Yip, G.S., 2003. The Digital Transformation of Traditional Businesses. MIT Sloan Management Review, 44(4), pp.34-41.

2. Atkinson, R., 2005. Prospering in an era of economic transformation. Economic Development Journal, Summer, pp.33-38.

3. Basole, R.C., 2016. Accelerating Digital Transformation Visual Insights from the API Ecosystem. IT Pro (December), pp.20-25.

4. Berman, S.J., 2012. Digital transformation: Opportunities to create new business models. Strategy \& Leadership, 40(2), pp.16-24.

5. Boddy, D. \& Paton, R., 2005. Maintaining alignment over the long-term: Lessons from the evolution of an electronic point of sale system. Journal of Information Technology, 20(3), pp.141-151.

6. Chahal, M., 2016. The True Meaning of Digital Transformation. Marketing Week, (April), pp.16-20.

7. Clayton M.C., Raynor, M. \& McDonald, R., 2015. What is disruptive innovation? Harvard Business Review (December), pp.44-53.

8. Cooper, B.L. et al., 2000. Data Warehousing Supports Corporate Strategy at First American Corporation. MIS Quarterly, 24(4), pp.547-567.

9. Dehning, B., Richardson, V.J. \& Zmud, R.W., 2003. The Value Relevance of Announcements of Transformational Information Technology Investments. MIS Quarterly, 27(4), pp.637-656.

10. Ebrahimpur, G. \& Jacob, M., 2001. Restructuring for agility at Volvo Car Technical Service (VCTS). European Journal of Innovation Management, 4, pp.64-72.

11. Galliers, R., 1994. Information systems, operational research and business reengineering. International Transactions in Operational Research, 1(2), pp.159-167.

12. Gray, P. et al., 2013. Realizing Strategic Value Through Center-Edge Digital Transformation in Consumer-Centric Industries. MIS Quarterly Executive, 12(1), pp.115-117.

13. Gregor, S. et al., 2006. The transformational dimension in the realization of business value from information technology. Journal of Strategic Information Systems, 15, pp.249-270.

14. Harrington, R.J. \& Tjan, A.K., 2008. Transforming Strategy One Customer at a Time. Harvard Business Review (March 2008), pp.62-73.

15. Chienwattanasook, K., Wattanapongphasuk, W., Prianto, A., \& Jermsittiparsert, K. 2019. "Corporate Entrepreneurship and Business Performance of Logistic Companies in Indonesia." Industrial Engineering \& Management Systems 18 (3): 538-547.

16. Dawabsheh, M., Hussein, A., \& Jermsittiparsert, K. 2019. "The Triangular Relationship between TQM, Organizational Excellence and Organizational Performance: A Case of Arab American University Palestine.” Management Science Letters 9 (6): 921-932.
17. Jermsittiparsert, K., Siam, M., Issa, M., Ahmed, U., \& Pahi, M. 2019. "Do Consumers Expect Companies to Be Socially Responsible? The Impact of Corporate Social Responsibility on Buying Behavior.' Uncertain Supply Chain Management 7 (4): 741-752.

18. Syazali, M., Putra, F., Rinaldi, A., Utami, L., Widayanti, Umam, R., \& Jermsittiparsert, K. 2019. "Partial Correlation Analysis Using Multiple Linear Regression: Impact on Business Environment of Digital Marketing Interest in the Era of Industrial Revolution 4.0." Management Science Letters 9 (11): 1875-1886.

19. Sae-Lim, P. \& Jermsittiparsert, K. 2019. "Is the Fourth Industrial Revolution a Panacea? Risks toward the Fourth Industrial Revolution: Evidence in the Thai Economy." International Journal of Innovation, Creativity and Change 5 (2): 732-752.

20. Chatchawanchanchanakij, P., Arpornpisal, C., \& Jermsittiparsert, K 2019. "The Role of Corporate Governance in Creating a Capable Supply Chain: A Case of Indonesian Tin Industry." International Journal of Supply Chain Management 8 (3): 854-864.

21. Hartinah, S., Suharso, P., Umam, R., Syazali, M., Lestari, B., Roslina, R., \& Jermsittiparsert, K. 2020. “Teacher's Performance Management: The Role of Principal's Leadership, Work Environment and Motivation in Tegal City, Indonesia." Management Science Letters 10 (1): 235-246.

22. Haseeb, M., Hussain, H., Slusarczyk, B., \& Jermsittiparsert, K. 2019. "Industry 4.0: A Solution towards Technology Challenges of Sustainable Business Performance." Social Sciences 8 (5): 184.

23. Haseeb, M., Hussain, H., Kot, S., Androniceanu, A., \& Jermsittiparsert, K. 2019. "Role of Social and Technological Challenges in Achieving a Sustainable Competitive Advantage and Sustainable Business Performance." Sustainability 11 (14): 3811.

24. Haseeb, M., Kot, S., Hussain, H., \& Jermsittiparsert, K. 2019. "Impact of Economic Growth, Environmental Pollution, and Energy Consumption on Health Expenditure and R and D Expenditure of ASEAN Countries." Energies 12 (19): 3598

25. Huda, S., Tsani, I., Syazali, M., Umam, R., \& Jermsittiparsert, K. 2020 "The Management of Educational System Using Three Law Auguste Comte: A Case of Islamic Schools.” Management Science Letters 10 (3) (In press), DOI: 10.5267/j.msl.2019.9.018.

26. Usak, M., Kubiatko, M., Shabbir, M., Dudnik, O., Jermsittiparsert, K., \& Rajabion, L. 2019. "Health Care Service Delivery Based on the Internet of Things: A Systematic and Comprehensive Study." International Journal of Communication Systems 32 (14): e4179.

27. Jermsittiparsert, K., Ambarita, D., Mihardjo, L., \& Ghani, E. 2019. "Risk-Return through Financial Ratios as Determinants of Stock Price: A Study from ASEAN Region.” Journal of Security and Sustainability Issues 9 (1): 199-210.

28. Thabhiranrak, T. \& Jermsittiparsert, K. 2019. "Towards Sustainable Functioning of Organization: Women Empowernment and Corporate Management Culture.” Journal of Security and Sustainability Issues 9 (1): 321-332.

29. Chienwattanasook, K. \& Jermsittiparsert, K. 2019. "Impact of Entrepreneur Education on Entrepreneurial Self-Employment: A Case Study from Thailand." Polish Journal of Management Studies 19 (1): 106-116.

30. Jermsittiparsert, K., Sutduean, J., Sriyakul, T., \& Khumboon, R. 2019. "The Role of Customer Responsiveness in Improving the External Performance of an Agile Supply Chain." Polish Journal of Management Studies 19 (2): 206-217.

31. Jermsittiparsert, K., Sutduean, J., \& Sriyakul, T. 2019. "Effect of Service Innovation and Market Intelligence on Supply Chain Performance in Indonesian Fishing Industry.” Industrial Engineering \& Management Systems 18 (3): 408-417.

32. Jermsittiparsert, K., Namdej, P., \& Somjai, S. 2019. "Green Supply Chain Practices and Sustainable Performance: Moderating Role of Total Quality Management Practices in Electronic Industry of Thailand." International Journal of Supply Chain Management 8 (3): 33-46.

33. Somjai, S. \& Jermsittiparsert, K. 2019. "The Trade-off between Cost and Environmental Performance in the Presence of Sustainable Supply Chain." International Journal of Supply Chain Management 8 (4) 237-247. 
34. Jermsittiparsert, K. \& Sawasdee, A. 2012. "Formal Education for Non-Thai or Undocumented Person in Thailand amidst the Challenge of Nationalism and Transnationalism: A Case Study of Wat Sirimongkhol School, Samut Sakhon Province." Kasetsart Journal Social Sciences 33 (2): 203-213.

35. Kaltenecker, N., Hess, T. \& Huesig, S., 2015. Managing potentially disruptive innovations in software companies: Transforming from On-premises to the Ondemand. Journal of Strategic Information Systems, 24(4), pp.234-250.

36. Kaufman, I. \& Horton, C., 2015. Digital Transformation: Leveraging Digital Technology with Core Values to Achieve Sustainable Business Goals. The European Financial Review (December-January), pp.63-67.

37. Lawton, L., 2015. The Leader's role in managing change: Five cases of technologyenabled business transformation. Global Business and Organizational Excellence, (March/April), pp.28-42.

38. Matt, C., Hess, T. \& Benlian, A., 2014. Digital Transformation Strategies. Business \& Information Systems Engineering, 57(5), pp.339-343.

39. Porter, M.E., 1991. Towards a Dynamic Theory of Strategy. Strategic Management Journal, 12, pp.95-117.

40. Sebastian, I.M. et al., 2017. How Big Old Companies Navigate Digital Transformation. MIS Quarterly Executive, 16(3), pp.197-213.

41. Valdez-de-leon, O., Christensen, C. \& Valdez-de-leon, O., 2016. A Digital Maturity Model for Telecommunications Service Providers. Technology Innovation Management Review, 6(8), pp.19-32. 